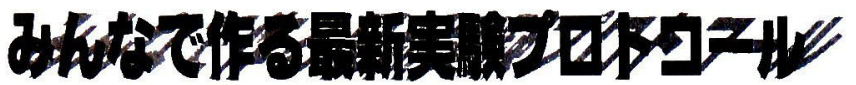

\title{
PCR 法による遺伝子破壊コンストラクトの作製法
}

桑山 秀一*, 田仲 可昌 筑波大学生物科学系

*日本学術振興会特別研究員

\section{1.はじめに}

DNA シーケンシング技術の発展により，ゲノム計画は 急速に拡大・進行し，多くの生物種において膨大な DNA 配列情報が入手可能になっている。この現状は単にゲノム 構造の解明と遺伝子情報を提供しただけでなく，生命科学 分野での研究様式を網羅的かつ包括的な方向に大きく変革 したといってあ良いであろう。これに伴って，ポストシー ケンスよしての遺伝子の機能解析も網羅的かつ体系的に行 われることが要求されてきている.

遺伝子の機能解析法の一つに, 遺伝子破壊法が挙げられ る.これは，標的遺伝子の機能を特異的に消失させ，その 結果起こる細胞あるいは個体レベルでの生物学的・生理学 的変化を解析することにより標的遺伝子の機能を解明しよ うとする方法である．通常は，形質転換体を選択するため のマーカー遺伝子（通常は発現カセットの形として）が挿 入された遺伝子領域 DNA をエレクトロポレーションなど で細胞に導入し，相同組換えを利用して染色体上の標的遺 伝子とそっくり置換させる形で行われる（図 1)。これは醉 母からマウスに至る多くの生物において頻繁に用いられて いる手法であるが, 現在において遺伝子機能の解析方法と して非常に重要な手法の一つである.

ここで用いられる遺伝子破壊コンストラクトの作製につ いては，これまで種々の方法が考案されてきた，最もス夕 ンダードな方法は, まず目的遺伝子の DNA 断片をクロー ニングし，標的遗伝子の適当な制限酵素部位にマーカー遺 伝子を挿入し，遺伝子破壊コンストラクトを完成させる方 法である（図 2a）。しかしながらこの方法では，標的遺伝 子のクローニングに手間がかかり，また適当な制限酵素部 位の有無によってコンストラクトの作製が制約を受けてし まう。これに対し，酵母においてはワンステップ PCRに よる方法が用いられている（図 2b)。これは標的遺伝子と マーカー遺伝子の両方の配列を含むキメラプライマーを使 って，マーカー遺伝子を PCR 法により増幅することによ り，両端に標的遺伝子の相同配列を有する遺伝子置換用

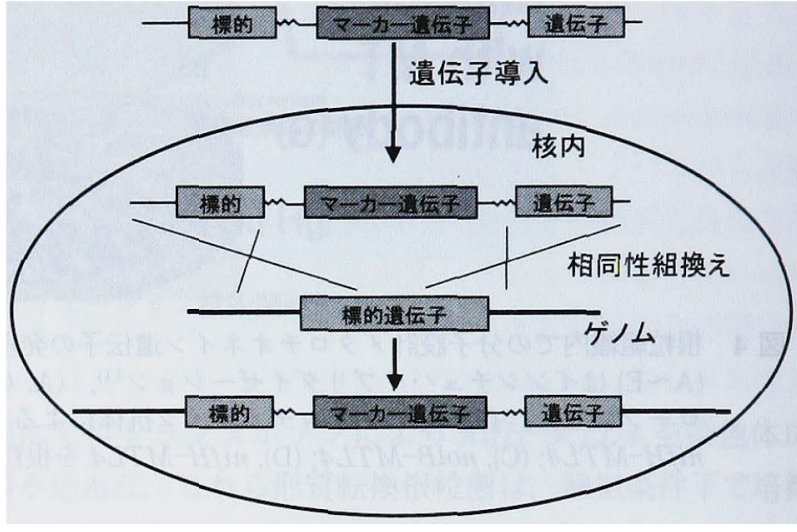

図 1 相同性組換えによる遗伝子破壊法の原理

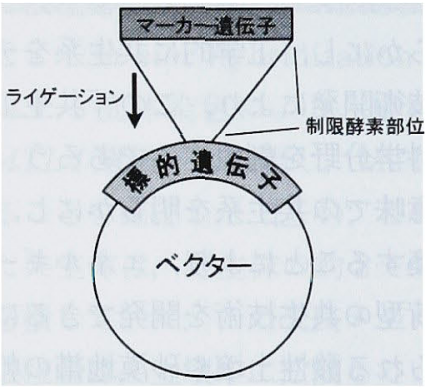

a クローニング法

（久点: 通当な制限磷秦部位と クローニング㮠作が必要)

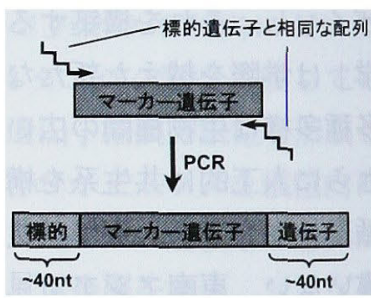

b ワンステップPCR法

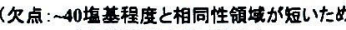
相同組換え效率が低()
図 2 従来の遺伝子破壊コンストラクトの作製法

DNA 断片を作製する方法である [Baudin et al.: Nucl. Acids Res., 21, 3329-3330 (1993)]. これは非常に簡便な 方法であるが，長いプライマーが必要なことと，PCR 法で は相同部分の配列の長さをせいぜい 30〜 40 bp にしかで きないため遺伝子置換の効率が悪いという欠点がある.

われわれの研究室では細胞性粘菌の cDNA 解析を行っ ており，遺伝子機能の解析のために遺伝子破壊株の作製を ハイスループットで行う必要が出てきた．そこで，上記の 遺伝子破壊コンストラクト作製法の「時間がかかる，相同 領域の長さ・位置を自由に設計できない.」という欠点を 補う方法を開発した。この方法により，制限酵素やDNA 
リガーゼ，クローニングベクターを一切用いずたった 2 ラ ウンドの PCR 操作だけで, 標的遺伝子との相同領域の位 置や長さを思いどおりに設計した遺伝子破壊コンストラク トを作製することができる，本稿においては，この遺伝子 破壊コンストラクト作製法の詳細と留意点を説明する.

\section{PCR 法による遗伝子破壊コンストラクトの作製の} 原理之実際

遺伝子破壊コンストラクトの構造は, 形質転換体を選択 するのに必要なマーカー遺伝子の両脇に標的とする遺伝子 領域の適当な長さをむった $5^{\prime}$ 側断片と $3^{\prime}$ 側断片をつなげ たものである，要は，適当な DNA 断片をつなげてこの構 造をむった遺伝子断片を作製すれば遺伝子破壊コンストラ クトとしての機能は満たすことになる.

われわれが開発した方法は DNA 断片の連結に fusion PCR 法を利用してDNA 断片を一気につなげ, 同時に増幅 してしまおうというアイデアに基づいている，作製法の流 れを図 3 に示した。

段階 1：まず，標的遺伝子領域の $5^{\prime}$ 側断片と $3^{\prime}$ 側断片を 増幅するためのプライマーを四つ用意する。このとき $5^{\prime}$ 側 断片の内側（プライマーB）はマーカー遺伝子の $5^{\prime}$ 側端 （プライマーE）と相同配列をあつようにキメラプライマ 一にしておく. 同様に, $3^{\prime}$ 側断片の内側 (プライマーC) は マーカー遺伝子の $3^{\prime}$ 側端（プライマーF）之相同配列をむ つようにキメラプライマーにしておく，このときマーカー 遗伝子の端に対する相同配列の長さは $20 \mathrm{mer}$ 程度以上に しておいた方が良い，また，われわれはマーカー遺伝子を 一般的なクローニングベクターである pBlueScriptや pUCなどのマルチクローニングサイトに挿入している. そのため, 使用するマーカー遺伝子の増幅を一般的なシー ケンシングプライマー配列を含むプライマーで行ってい る. 参考までに，われわれがブラストサイジン $\mathrm{S}$ 耐性マー カーにより細胞性粘菌遗伝子を破壊するときに用いている プライマー配列を表 1 にま之めた.

最初の PCR である標的遺伝子領域の $5^{\prime}$ 側断片と $3^{\prime}$ 側断 片とマーカー遺伝子の増幅は, ゲノムあるいはプラスミド を鋳型にして Taq な゙の一般的な耐熱性の DNA ポリメ
ラーゼを使用する。しかし，増幅の際にェラーが入ると相 同組換え効率が落ちることが考えられるので，できるだけ high-fidelity の DNA ポリメラーゼを使用することが望ま しい．ただ，DNA ポリメラーゼは鋳型との相性があるの で生物種やゲ/ム DNA 調製法によって各自検討してもら いたい，われわれの研究室では，細胞性粘菌のゲノム DNA との相性を考慮して，全ゲノムを鋳型にしてDNA 断片を増幅するときは Roche Expand Long Template PCR system あるいは TAKARA の Pyrobest を使用して いる. 反応条件は会社のプロトコール従い $25 \mu \mathrm{L}$ スケール で, $94^{\circ} \mathrm{C} \rightarrow 2 \min \left(94^{\circ} \mathrm{C}, 20 \mathrm{~s} \rightarrow 55^{\circ} \mathrm{C}, 3 \mathrm{Ds} \rightarrow 68^{\circ} \mathrm{C}, \mathrm{kbp} \times 1\right.$ $\min ) \times 25 \rightarrow 68^{\circ} \mathrm{C}, 2$ min で増幅している. 増幅した PCR 反応液から未反応プライマーを取り除くため, 反応液をア ガロース電気泳動後目的の DNA 断片を切り出し, 抽出す るか，市販のプライマー除去キットを用い目的の DNA 断 片を精製する. 未反応プライマーは次の段階である fusion
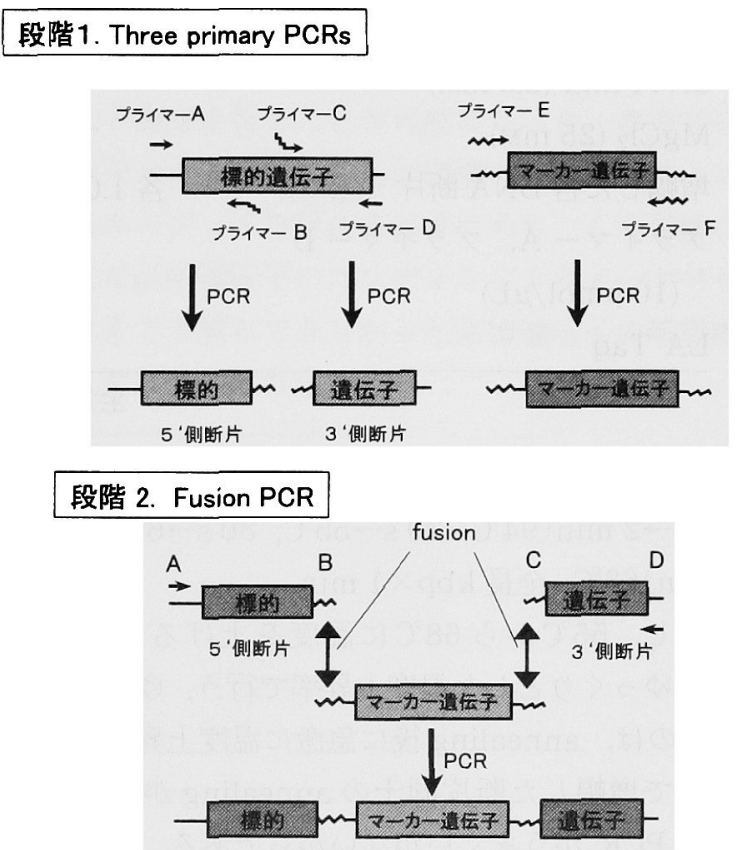

遺伝子破壊コンストラクト

図 3 PCR 法による遺伝子破壊コンストラクトの効率的作 製法

表 1 遺伝子破壊コンストラクトの作製に使用するプライマー配列

マーカー遺伝子増幅に使用するプライマー配列

$5^{\prime}$ 側 CAGGAAACAGCTATGACCATGATTAC (26mer)

$3^{\prime}$ 側 CGACGTTGTAAAACGACGGCCAGTG (25mer)

標的遺伝子の $5^{\prime \prime}$ 断片と $3^{\prime}$ 断片増幅に使用するキメラプライマー配列

5断片 $3^{\prime}$ 側 GTAATCATGGTCATAGCTGTTTCCTGCAG $+20 \mathrm{mer}$ 程度の標的遺伝子相補鎖配列

$3^{\prime}$ 断片 $5^{\prime}$ 側 CACTGGCCGTCGTTTTACAACGTCGAC+20mer 程度の標的遺伝子配列 
PCR を強く阻害してしまい反応がうまくいかないので， この操作で完全に未反応プライマーを取り除く必要があ る.一方, $\mathrm{EtBr}$ を取り除く操作の必要はない，

ところで，5断片と $3^{\prime}$ 断片を増幅する際，直接ゲノム DNA を鋳型にして増幅しても構わないが，目的としない 遺伝子領域を間違って増幅してしまう可能性もある。その 可能性を検証するために，われわれはゲノムを鋳型にして 両端のプライマー（プライマーA とプライマーD；図 3） を用いてまず目的の遺伝子の全長を増幅している，その 後，その増幅断片を鋳型にして5断片と3'断片を増幅し ている.こうすることによって，内部のプライマー（プラ イマーB とプライマーC) で再度チェックすること（いわ ゆるネストPCR）になり，目的の遺伝子が正しく増幅され ているかの確認になる。

段階 2：fusion PCR は以下の操作で行う.

DNA ポリメラーゼはTAKARA の LA Taq を使用し以 下の組成で PCR 溶液を作製する。

10X LA 緩衝液 $\left(\mathrm{Mg}^{2+}\right.$ free)

$2.5 \mu \mathrm{L}$ dNTPmix $(2.5 \mathrm{~mm})$ $2.5 \mu \mathrm{L}$ $\mathrm{MgCl}_{2}$ (25 mM) $4.0 \mu \mathrm{L}$ 増幅した各 DNA 断片（三つ） プライマーA，プライマーD $(10 \mathrm{pmol} / \mu \mathrm{L})$

各 $1.25 \mu \mathrm{L}$ LA Taq $0.25 \mu \mathrm{L}$

全量 $25.0 \mu \mathrm{L}$

PCR の条件は，基本的には以下のように行っている. $94^{\circ} \mathrm{C} \rightarrow 2 \min \left(94^{\circ} \mathrm{C}, 20 \mathrm{~s} \rightarrow 55^{\circ} \mathrm{C}, 30 \mathrm{~s} \rightarrow 68^{\circ} \mathrm{C}\right.$, 全長 $k b p$ $\times 1 \mathrm{~min}) 68^{\circ} \mathrm{C}$, 全長 $\mathrm{kbp} \times 1 \mathrm{~min}$

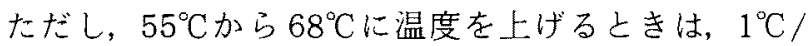
$10 \mathrm{~s} の$ っくりとした温度上昇率で行う。ゆっくり温度を 上げるのは，annealing 後に急激に温度上昇をさせると第 一段階で増幅した断片同士の annealing が外れやすく, fusion PCR がうまくいかないからである，反応に加える 增幅した各 DNA 断片の量であるが，これは上記のように 大雑把な量でる問題はない，筆者らはプライマーを除いた DNA 断片を上記の上うに適当量加えている，極端に言え ば，一分子でも fusion PCR がうまくいけば，目的のコン ストラクトの増幅が得られるはずである。しかしながら， fusion PCRがうまくいかない原因の一つとして，加える 各 DNA 断片量加極端に少ないこよや偏っていることも挙 げら机るのでううくいかないときは各 DNA 断片の量を 確認し，各 DNA 断片を増量するあるいは分子数を均一に することを検討してみると良いか。

上述の組成は $25 \mu \mathrm{L}$ スケールであるが，必要量の遺伝子
破買コンストラクトを一気に作製するために PCR をスケ ールアップしてあ良い，筆者らは $200 \mu \mathrm{L}$ スケールの PCR を行うことによって，1回の形質転換実験に必要量な 10 $\mu g$ を得ている. しかし, fusion PCR が正確に行われたか どうかを確認する意味で, 最初に少量で fusion PCR を行 い，增えた目的の遗伝子破壊コンストラクトを再度大容量 で增幅することを勧める.

できあがったものはプライマーなど除く必要はなく，工 タノールで沈殿させてそのまま形質転換に使用している。 ちなみに, 細胞性粘菌の cAMP 依存性リン酸化タンパク 質の触媒サブユニットに対する遺伝子破壊コンストラクト をブラストシジンS 耐性遺伝子発現カセットを用いて作 製した場合, 得られた形質転換体のうち約 90\%が遗伝子 破壊株であった [Kuwayama et al.: Nucl. Acids Res., 30, $\mathrm{e} 2(2002)]$.

\section{3. 留意点とトラブルシューティング}

遺伝子破壊コンストラクトの作製を計画する際に考慮す べき重要な点は，(1) 遺伝子のどの領域に，(2)どのような マーカー遗伝子を挿入し, (3) どの程度の長さの相同領域 断片を用いればよいのか？ということである。これらの 点は生物の種類やゲ/ムの構造によって異なっており，作 製時にこれらの条件を検討する必要がある．細胞性粘菌の 場合は，遺伝子の中央にマーカー遺伝子を置き，両側に約 $1 \mathrm{kbp}$ 以上の $5^{\prime}$ 側断片と $3^{\prime}$ 側断片それぞれをつなげたも のが高い相同性組換え効率が得られると考えられている が，標的遗伝子によってはマーカー遗伝子の位置をずらし たり両側の遺伝子断片長を調節したりして相同組換えの効 率を検討しなればならない場合もある。あまりに組換え 効率が低い場合には，相同領域断片の長さや位置を変えた あのをいくつか試してみることあ必要であろう。

われわれが実験を行っていて屯，fusion PCR がうまく いかないことがあった。これは，DNA ポリメラーゼの種 類を検討することと， annealing からプライマーの伸長反 応温度まで温度をゆっくりと上昇させることで解決でき た。 また，目的の PCR 産物以外の副生成物が時折生成さ れるこ上があるが，われわれの実験においてはこれらの副 生成物が遺伝子破壊株の作製や効率に怙いて問題になった ことはなかった，いずれにせよ，これらの副生成物が問題 を起こしたかどうかは，形質転換体の PCRやサザン解析 などによる確認作業でチェックできるはずである。

まれに，いろいると fusion PCR の条件を検討しても， 遺伝子破壊コンストラクトの作製がうまくいかない場合が あった。このときは以下の変法を試している.

一つは, fusion PCR の際にプライマーを加えないで 10 
Vol. 77, No. 2,2003 )

cycles ほど PCR 反応を行い，その後プライマーを加え再 度 20 cycles ほど PCR を行うことである，こうすること により，fusion PCR 産物を確実に得ることができた。

これであうまくいかないよきは，マーカー遺伝子の両端 の相同配列を变えて最初から遺伝子破壊コンストラクトの 作製を試みるのも一つの方法である。しかし，プライマー の設計に要する時間やコストの面であまり得策ではない． われわれは，あらかじめ表で示したように fusionさせる 側のプライマーにPst I（CTGCAG；表 1, 下線）あるいは Sal I（GTCGAC; 表 1, 二重下線）制限酵素認識配列を入 れておいて，段階 1 でできあがった相同性領域 PCR 断片 をこれらの制限酵素で切断した後マーカー遺伝子とライゲ ーションすることにより遺伝子破壊コンストラクトを作製 している.これは一番外側のプライマー(プライマーA と D；図3）を用いた PCR により必要量まで増幅し形質転換 に用いることができる.

これとは別に，これらの制限酵素配列は，できあがった DNA 断片が正確に順番ど扔りにつながっているかどうか の確認やサザン解析の際に香利用している。

\section{5. おわりに}

本稿では，PCR 法を用いた簡便かつ効率的な遺伝子破 壞コンストラクトの作製方法について解説した。本方法の 応用として, 以下のことが挙げられる。

（1）本方法は fusion PCR を利用し DNA 断片を随意に
PCR 法による遗伝子破壊コンストラクトの作製法 153

連結し，增幅することを目的としているので，基本的に遺 伝子破壊コンストラクトの作製だけではなく，発現ベク夕 一の作製も可能である.

(2) ノックアウトマウス作製の系では, 目的以外の場所 に挿入(ランダムインテグレーション)されたクローンを 選択しないようにするため，ネガティブセレタションマー カ一を遺伝子破壊コンストラクトの端につなげておく［ポ ジティブーネガティブセレクション; Mansour et al: Nature, 336, 348-352 (1988)] が, 本方法においてはつなげ る DNA 断片の数には制限はないので，このような遺伝子 破壊コンストラクトの作製にも本方法は適応できる。

(3) 近年，遺伝子そのものをバクテリオファージP1由 来の loxP配列で挟み，リコンビナーゼであるCre を発現 させることによって loxP 配列部位特異的に組換えを起こ させ遺伝子を除去する方法が盛んに行われている $[\mathrm{Gu} e t$ al.: Science, 265，103-106 (1994)]. この方法を応用して, 組織特巽的あるいは時期特暴的なプロモーターの下流にり コンビナーゼであるCre をつなぎ，組織特異的あるいは時 期特異的に遣伝子破壊を行うこと，いわゆるコンディショ ナルな遺伝子破壊を行うこ上が可能になった，本方法を用 いればコンディショナルな遺伝子破壊コンストラクトの作 製すハイスループットで行えるはずである。この方法によ り作製された必須遺伝子のコンディショナルノックアウト 株が，これまで予想もできなかった必須遺伝子の新規機能 を明らかにするかむしれない。 